\title{
UNUSUAL CONCENTRATIONS OF ANDHILL CRANES DURING THE BREEDING SEASON
}

H. KOONZ, Manitoba Department of Natural Resources, Box 14, 1495 St. James reet, Winnipeg, Manitoba. R3H OW9

On 14 and 15 June 1989, Blair Mcahon and I observed large numbers of lult Sandhill Cranes feeding in a recentgerminated grain field on the west side PTH \#276 near Waterhen $\left(51^{\circ} 47^{\prime} \mathrm{N}\right.$, $\left.35^{\prime} \mathrm{W}\right)$. Starting in mid-afternoon on June, cranes were noticed flying in m all directions. By 8:30 p.m., 86-90 anes had assembled on the field. At 55 p.m. all but a handful of birds had wn away. The area was also checked 15 June when at least 112 adult cranes re observed in the field at 6:30 p.m. ndhill Cranes typically aggregate in rly morning and late afternoon feeding cks during spring, fall and winter, but I uld not find reference to adults conntrated into feeding areas during the ceding season.' It may be that these birds were non-breeders spending the breeding season in the Westlake area. Non-breeding concentrations of Canada Geese are known to use traditional feeding areas, but this phenomenon has not been reported for Sandhill Cranes.

The observations seemed out of the ordinary given that young cranes should have been with their parents at that time of the year. Dry conditions and massive local fires likely contributed to poor 1989 Sandhill Crane productivity in Manitoba's Interlake, Westlake and boreal forest areas.

1 STEPHEN, W.J.D. 1967. Bionomics of the Sandhill Crane. Can. Wildl. Serv. Rept. No. 2. 48 pp. 